\title{
Forest biomass supply chain optimization for a biorefinery aiming to produce high-value bio-based materials and chemicals from lignin and forestry residues: A review of literature
}

\begin{tabular}{|r|l|}
\hline Journal: & Canadian Journal of Forest Research \\
\hline Manuscript ID & cjfr-2016-0336.R2 \\
\hline Manuscript Type: & Review \\
\hline Complete List of Authors: & $\begin{array}{l}\text { Dessbesell, Luana; Lakehead University, Faculty of Natural Resources } \\
\text { Management } \\
\text { Xu, Chunbao (Charles); Institute for Chemicals and Fuels from Alternative } \\
\text { Resources (ICFAR), Department of Chemical and Biochemical Engineering, } \\
\text { Western University } \\
\text { Pulkki, Reino; Lakehead University, Faculty of Natural Resources } \\
\text { Management } \\
\text { Leitch, Mathew; Lakehead University, Faculty of Natural Resources } \\
\text { Management } \\
\text { Mahmood, Nubla; Institute for Chemicals and Fuels from Alternative } \\
\text { Resources (ICFAR), Department of Chemical and Biochemical Engineering, } \\
\text { Western University }\end{array}$ \\
\hline Keyword: & $\begin{array}{l}\text { biomass-to-energy, biomass-to-materials and chemicals, economic } \\
\text { optimization, lignocellulosic residues, value-added bio-based products }\end{array}$ \\
\hline
\end{tabular}

\section{SCHOLARONE \\ Manuscripts}


1 Forest biomass supply chain optimization for a biorefinery aiming to produce high-

2 value bio-based materials and chemicals from lignin and forestry residues: A review of

3 literature

4

5 Luana Dessbesell ${ }^{\mathrm{a} *}$, Chunbao (Charles) $\mathrm{Xu}^{\mathrm{b} *}$, , Reino Pulkki ${ }^{\mathrm{a}}$, Mathew Leitch ${ }^{\mathrm{a}}$, Nubla

6 Mahmood $^{\mathrm{b}}$

7

$8 \quad{ }^{a}$ Lakehead University, Faculty of Natural Resources Management, Braun Building, BB1007D

$9 \quad$ - 955 Oliver Rd, Thunder Bay, ON P7B 5E.

$10{ }^{\mathrm{b}}$ Institute for Chemicals and Fuels from Alternative Resources (ICFAR), Department of

11 Chemical and Biochemical Engineering, ICFAR, Rm. 108 and Room CMLP 2335, Western

12 University

13

14 Email: ldessbes@lakeheadu.ca(L.D);nmahmoo2@uwo.ca(N.M);

15 mathew.leitch@lakeheadu.ca(M.L); rpulkki@lakeheadu.ca(R.P.); and,cxu6@uwo.ca

16 (C.X.).

17 *Corresponding authors: ldessbes@lakeheadu.ca (L.D) Phone: (807) 766 -7127 and,

18 cxu6@uwo.ca (C.X.) Phone: 519-661-2111 ext.86414.Fax: 519-661-4016 
19 Abstract

20 Technological development has enabled the production of new value-added products from

21 lignocellulosic residues, such as lignin. This has allowed the forest industry to diversify its

22 product portfolio and maximize the economic returns from feedstock, while simultaneously

23 working towards sustainable alternatives to petroleum-based products. Although previous

24 research has explored industrial-scale production opportunities, many challenges persist

25 including the cost of woody biomass and its supply chain reliability. While numerous studies

26 have addressed these issues, their emphasis has traditionally been on bioenergy, with little

27 focus on biochemicals and biomaterials/bio-products. This review seeks to address this gap

28 through a systematic study of the work recently reported by researchers. A lot of work has

29 been published from United States and Canada with an emphasis on bioenergy production

$30(84.8 \%), 4.6 \%$ of the work is focused on biomass-to-materials or chemicals, and $10.6 \%$

31 addressed both. Between 2012 and 2015, the majority of published research is focused on

32 "biomass-to-materials and chemicals" and both "biomass-to-energy and biomass-to-materials

33 and chemicals". This fact highlights recent interests in diversified biorefinery portfolios.

34 However, further work concerning forest biomass supply chain optimization, and new high-

35 value bio-based materials and chemicals is necessary.

37 Keywords: biomass-to-energy, biomass-to-materials and chemicals, economic optimization,

38 lignocellulosic residues, value-added bio-based products. 
39

40

\section{Introduction}

Countries around the world are adopting laws/policies intended to lower Greenhouse

Gas (GHG) emissions, which results in an increasing interest in alternative renewable sources for producing bioenergy, biochemicals, and biomaterials. Despite this interest, according to the International Energy Agency (IEA), oil, natural gas and coal still account for almost $81.7 \%$ of the world's current primary energy supply (Bell et al. 2014). Moreover, many industrial chemicals and synthetic materials are still dependent on petroleum-derived products (Kurian et al. 2013). For instance, $42 \%$ of the petroleum revenue came from chemicals, plastic and rubber. Surprisingly, this category consumes only $4 \%$ of petroleum (Werpy, 2009).

As an alternative feedstock to petroleum-based products, lignocellulosic biomass has been recognized as a promising resource for the production of non-energy commodities, such as chemicals, fibres, plastics and construction materials because of its chemical properties and abundance (Fahd et al. 2011; Iqbal et al. 2013; Isikgor and Becer 2015). Additionally, lignocellulosic biomass provides means of helping the forest sector transition into a more diverse, market-driven industry, while concurrently improving its environmental footprint (Thiffault et al. 2014). Thus, the biorefining approach has become a favourable pathway to obtain value-added products from forest and mill residues. The biorefinery concept is defined by the IEA - Task42 Biorefining, as the "sustainable and synergetic transformation of lowvalue biomass into marketable food and feed ingredients, products (chemicals, materials) and energy (fuels, power, heat)" (Bell et al. 2014).

In this context, researchers have been working intensively to improve biomass conversion technologies towards commercial-scale facilities (Hughes et al. 2013). However, despite the increased efficiency of the technology in the last decade, ongoing challenges 
64 related to the feedstock logistics and biomass valorization have resulted in only a small

65 number of operational industrial biorefineries (Kurian et al. 2013).

66 While the biorefinery concept has emerged as an alternative way to petroleum

67 dependence, the rising demand for biomass from the traditional forest industry and the

68 emerging bioproducts industry have increased the complexity of multilevel supply systems.

69 This creates a need for the integrated biomass supply chain management (BSCM) approaches

70 (Iakovou et al. 2010). Therefore, a method for designing profitable biomass supply chains

71 (BSC), which can also accommodate these aforementioned challenges, is vital to the long-

72 term economic viability of this emerging industry (Sukumara et al. 2014; An and Wilhelm

73 2014).

74 The development of an efficient BSC to provide a low-cost biomass feedstock

75 requires detailed investigation and analysis. In recent years, there have been an increasing

76 number of literature reviews on BSC. The following summarizes the subjects addressed by

77 recent review papers:

78 - main concerns related to bioenergy BSC and logistics (e.g. Gold and Seurig, 2011 and

$79 \quad$ Kurian et al. 2013);

80 - effect of different feedstocks types on the BSCM (e.g. Iakovou et al. 2010 and Kurian

$81 \quad$ et al. 2013);

82 - multi-criteria decision-making methods were addressing problems arising within the

83 bioenergy sector (e.g. Scott et al. 2012);

84 - bio-fuel BSC under uncertainties (e.g. Awudu and Zhang, 2012);

85 - deterministic and stochastic models applied in bioenergy value chain optimization

$86 \quad$ (e.g. Shabani et al. 2013);

- assessment and optimization of forest biomass supply chain (FBSC), considering

economic, social and environmental aspects (e.g. Cambero and Sowlati, 2014); 


\section{2.1 Narrative literature review} subjects is very limited or missing. chemicals.

\section{Methods}

\section{1}

- development of energy BSC optimization frameworks (e.g. Elia and Floudas, 2014). Strategic challenges and issues with design, planning, and management of BSC (e.g. Mafakheri and Nasiri, 2014); and,

- $\quad$ multi-scale modeling and optimization of BSCs (e.g. Yue et al. 2014).

Additionally, there are a number of literature reviews regarding thermochemical technologies and the opportunities associated with lignocellulosic biomass (e.g. Iqbal et al. 2013; Isikgor and Becer 2015). While studies examining FBSC and conversion technologies to produce bio-based value-added products are quickly evolving, a review covering those

To fill this gap in the literature, this work endeavours to answer some questions such as "What products shall be targeted in a biorefinery based on FBSC optimization?" To accomplish this, the remainder of this work is organized into two sections. The first part outlines recent advancements in conversion technologies and bio-based products from forest residues focusing on lignin. The second part presents a systematic review of FBSC studies. This paper contributes to the body of knowledge by: (i) summarizing recent achievements in the production of bio-based products from lignin and forest residues; (ii) providing an overview of BSC studies, based on their year of publication, research objectives, country of origin and journal; and, (iii) identifying the bioproducts targeted in the FBSC optimization studies and summarizing the number of articles that addressed bio-based materials and 
113 To provide the background information on thermochemical technologies to produce

114 value-added bio-based chemicals and materials from lignin and forest residues a narrative

115 review was performed in the first section of this paper.

116 A narrative review is a combination of published information, where it typically

117 summarizes the contents of each paper (Green et al. 2001). In this first section we focused on

118 the research work done by the research team of the Institute for Chemicals and Fuels from

119 Alternative Resources (ICFAR) and Lignoworks (The NSERC Biomaterials and Chemicals

120 Strategic Research Network: http://www.icfar.ca/lignoworks/) in Canada, which have

121 significantly contributed to the Canadian forest industry by generating alternative products

122 and technologies from forest and mill residues.

123 Publications from Canada were reviewed in this paper; the country is one of the

124 leading countries in research in this field, and can provide a considerable number of papers

125 satisfying a narrative review to cover the topic.

126

127 2.2 Systematic literature review

128 In this section, the literature on supply chain optimization is collected through a

129 search and screening of research and literature review papers that address different

130 components of the BSC. Secondly, a systematic review is presented, based on the process

131 described below.

132 The systematic review helps to identify the difference between real and presumed

133 knowledge through mapping out areas of uncertainty, determining in what fields little

134 research has been done and identifying topics in which more research is necessary (Petticrew

135 and Roberts 2006). The systematic review followed five main steps: identifying key

136 terms/words, locating/searching literature, checking publications applicable to the topic,

137 classifying the literature and writing the literature review. 
138 The keyword "biomass* supply* chain*" was searched in the ISI Web of Knowledge

139 (WOK), resulting in the retrieval of 979 documents. All database years of ISI were taken into

140 consideration, and the results were saved in End Note Web for external review and

141 verification (a complete list of documents can be obtained by contacting the first author). The

142 data were then entered into Microsoft Excel for analysis. The review focused on English

143 language peer-reviewed literature documenting FBSC technical and economic optimization.

144 Therefore, to be included the paper had to be considering at least one forest-based feedstock

145 also perform a BSC techno-economic optimization.

146

147 3. A narrative literature review on alternative sources and thermochemical technologies for production of bio-based chemicals and materials

\subsection{Alternatives sources for bio-based products}

Energy crops, forest and agriculture biomass residues are renewable resources that can potentially offset future petroleum shortages while decreasing GHG emissions and not compromising food supply (Bell et al. 2014). Lignocellulose is a major structural component of woody and non-woody plants and consists of cellulose, hemicellulose and lignin (Menon and Rao 2012). secondary cell walls (Sjöström 1993). Hemicelluloses are heteropolysaccharides that also

158 function as supporting materials in the cell walls (Sjöström 1993). Lastly, "Lignin is a complex three-dimensional biopolymer of aromatic alcohols" (Ferdosian et al. 2014). After cellulose, lignin is the second most abundant renewable natural polymer, accounting for

161 between $15 \%$ and $40 \%$ of stem wood, depending on species (Holladay et al. 2007; Novaes et 162 al. 2010). 
163 Recently, cellulose has become a source material for a variety of products, in addition 164 to traditional products, such as pulp and paper. The cellulose and hemicellulose-derived 165 carbohydrates can be refined into various value-added bio-based products, such as alcohols, 166 esters and carboxylic acids, through so-called "sugar platform" biorefineries (Cheng et al.

167 2010). Moreover, the world's first cellulose nano-crystalline plant was built in Canada with a 168 capacity of one $t \cdot$ day $^{-1}$ (Hamel 2016).

169 Innovative technologies to create value-added and high-value bio-based products have 170 led to improved usage of forest harvesting and mill residues, such as kraft lignin. The primary 171 source of technical lignin is the pulp and paper industry (Mahmood et al. 2013). According 172 to Moshkelani et al. (2013), the kraft lignin pulping residues can increase the revenue margin 173 of mills through conversion into higher valued marketable products such as biofuels, 174 synthetic gas and chemicals.

175 In the kraft pulping process, only $42 \%$ to $44 \%$ of softwood biomass after bleaching, 176 and about $50 \%$ of hardwood is converted into pulp, and the residue (mainly hemicelluloses 177 and lignin) is combusted in the recovery boiler (Moshkelani et al. 2013). Laurichesse and 178 Avérous (2014) estimated that annual global production of lignin is over 70 million tonnes, 179 around $95 \%$ of which is burned in recovery boilers for steam and power generation. Only 180 about $5 \%$ of lignin (mainly lignosulphonate) is utilized for production of value-added bio181 based products, such as dispersants, adhesives and surfactants.

182 Lignin is an exceptionally abundant raw material and, therefore, offers an opportunity 183 for lignocellulosic biorefineries. According to Hughes et al. (2013), biorefining technologies 184 are available to utilize and fractionate lignocellulosic feedstock to produce intermediate and 185 final products (Hughes et al. 2013). However, there are a few kraft lignin plants in North 186 America, including the Mead-Westvaco in South Carolina, USA, which produces 187 approximately $20,000 \mathrm{t} \cdot \mathrm{yr}^{-1}$ of kraft lignin (Huang 2014). In 2013, Domtar started to produce 
$18875 \mathrm{t} \cdot \mathrm{d}^{-1}$ of kraft lignin at its Plymouth, North Carolina plant (Huang 2014). A commercial-

189 scale kraft lignin production plant with a targeted capacity of $30 \mathrm{t} \cdot \mathrm{d}^{-1}$ is under construction in

190 Hinton, Canada based on the LignoForce ${ }^{\mathrm{TM}}$ system created by FPInnovations. Also, a lignin

191 precipitation pilot plant, the first facility of its kind in North America, is installed at Resolute

192 Forest Products in Thunder Bay, Ontario, with capacity for $100 \mathrm{~kg} \cdot \mathrm{d}^{-1}$ (Canadian Biomass

193 2013).

194 Holladay et al. (2007) considered six scenarios where 225 million tonnes of lignin

195 were utilized for power, transportation fuels, products and chemicals, both individually and in

196 various combinations. When lignin is used for purposes other than power, the overall revenue

197 increase is \$12-35 billion. However, significant technological development will be required

198 to seize the full value benefit.

199 Research in non-traditional wood products that can be produced alongside traditional

200 products has been playing a prominent role in expanding the current wood product portfolio,

201 to take advantage of new market opportunities (Blair 2013). A biorefinery model proposed by

202 the Canada Bio-pathways Project is based on extracting the largest possible value from a

203 forest feedstock. Products originating from this process include both traditional and novel

204 ones that satisfy the primary criteria that the highest possible value must be generated at

205 every stage. Ordinarily, heat and power are a necessary part of the combination (Browne et

206 al. 2011).

207 Specialty chemicals are said to be promising elements of a forest biorefinery products

208 portfolio because they have the highest profit margins compared to pulp and paper products,

209 and less competition within the market. This allows biorefineries to reduce their direct

210 competition with well-established commodity petrochemical products (Mansoornejad 2012).

211 Browne et al. (2011) analyzed the relationship between annual market size and price

212 of forest products. They concluded that the products with higher market price have a smaller 
213 market size, and vice versa. For instance, polyphenols (biomass-derived specialty chemicals),

214 have a market size of $10^{4} \mathrm{~kg}$ per year, and a market price higher than US\$100/kg. In contrast,

215 cellulose-based fibres have a world market of the order of $10^{11} \mathrm{~kg}$, but regular sales prices are 216 of the order of $\$ 1 / \mathrm{kg}$.

\subsection{Thermochemical conversion technologies}

219 Commercial scale conversion of lignocellulosic materials to value-added bio-based 220 products is still a challenging proposal. According to Ghatak (2011), an upgraded technology

221 for lignin isolation from black liquor, and breakthroughs in industrial chemistry and chemical technology for value-added products from lignin can profoundly improve a lignocellulosic 223 biorefinery.

There are a number of conversion technologies available to convert biomass residues into a range of biofuels and chemicals (Srirangan et al. 2012). In this paper, a short overview of recent papers addressing lignin conversion technologies for chemicals and materials is presented. For an in-depth review the following papers are recommended: Zhang et al. 2010a; Laurichesse and Avérous (2014) are useful literature sources. air/oxygen, steam, $\mathrm{CO}_{2}$ or their combinations for converting lignocellulosic biomass into low

233 to medium Btu (British thermal unit) fuel gasses (Hurley et al. 2010). For Feng et al. (2015) there are two pathways to obtain renewable phenol alternatives. The first is to extract chemical components such as lignin and alkaline extractives from lignocellulosic biomass.

236 The second is to convert lignocellulosic biomass via various thermochemical processes (i.e.,

237 phenolysis, liquefaction and pyrolysis) into phenolic bio-crude, bio-oil or pyrolysis oil. 
Lignin can be degraded or decompose into oligomeric and monomeric phenolic compounds by different processes, such as hydrolysis and pyrolysis (Pandey and Kim 2011).

These compounds then become potential sources of biophenols for replacing petroleum-

based phenols in the production of phenol formaldehyde (PF) resins (Cheng et al. 2011).

fuels and value-added chemicals (Feng et al. 2015). High-pressure direct liquefaction

technology was found to be superior when compared to pyrolysis technology as it produces liquid oils with much greater caloric values (Yang et al. 2009a). Bio-oil products from fast pyrolysis contain high contents of water and oxygen leading to relatively low heating values.

In contrast, biomass direct liquefaction processes produce liquid oil products (bio-crude) of a greater heating value than those from pyrolysis bio-oils (Li et al. 2011). converts wet biomass material or aqueous organic waste directly into a valuable hydrogen $\left(\mathrm{H}_{2}\right)$-rich syngas (Zhang et al. 2012). produce bio-based polymers, can be classified it into the following main groups: lignin fragmentation or de-polymerization into phenolic or other aromatic compounds for fine chemistry; synthesis of new chemical active sites to impart new reactivity to lignin; and, functionalization of hydroxyl groups to enhance their reactivity or responsiveness. Pandey and Kim (2011), in their literature review on thermochemical conversions of lignin, concluded that pyrolysis, gasification, hydrogenolysis, chemical oxidation and hydrolysis

261 lignin depolymerization. 
263 chemicals and materials was provided in a thesis by Huang (2014). The author concluded

264 that: lignin is a rich source of aromatics, which can be obtained by liquefaction or

265 depolymerization. These lignins have smaller molecular weight, less steric hindrance effects

266 and more active functional groups, which are desirable for the synthesis of bio-based

267 phenolic resins, polyurethane resins and epoxy resins. Pyrolysis lignin has low yields

268 generating a considerable amount of char; and, hydrothermal liquefaction provides various

269 benefits when compared to gasification, wet oxidation, and pyrolysis.

270

271

\subsection{Potential bio-based products from lignin and woody biomass}

The term bio-based product includes the traditional products of the forest industry and

a variety of chemicals, plastics, additives, bio-based plastics, fibres, reinforced plastics and

insulation materials (de Jong et al. 2012). Figure 1 summarizes the potential bioproducts from

lignocellulosic materials identified by Iqbal et al. (2013). In this paper we further classify the

BSC for final products according to EIA Bioenergy (Bell et al. 2014) definitions:

- Biomass-to-energy: power, heat and fuels;

- Biomass-to-materials and chemicals (non-energy) that can be further classified into two product groups: traditional wood, paper and textile products (e.g., cotton, pulp); and, synthetic chemicals and materials (e.g., plastics, fibres and nitrogen fertilizers).

highlighting the potential lignin bioproducts. Biomass to bioenergy and biofuels production is widely discussed in previous reviews, such as Hughes et al. (2013) and Williams et al. (2016). After an exhaustive screening, Kokossis et al. (2015) found that the promising products of a biorefinery portfolio are from C5 sugars, including the catalytic production of xylitol and C5 ethanol, C6 sugars, including C6 ethanol and Itaconic acid, and from lignin

287 derivatives such as PF resins and polyurethanes. 
Ferdosian et al. $(2014,2015)$ state that lignin may be the best candidate as a green

alternative to bisphenol A for the production of epoxy resin because of its aromatic

arrangement. Moreover, Mahmood et al. (2013) highlighted that kraft lignin is a source of

polyols, due to lignin's particular phenyl propanol structure and aryl alkyl ether bonding. In

292

the search for sustainable materials for building and construction, lignin was found to be a suitable substitute to phenol in the manufacturing of PF resins (Pandey and Kim 2011; Cheng et al. 2011).

Mahmood et al. (2013) propose a process that produced renewable polyols from kraft

lignin with desirable characteristics for rigid polyurethane foam synthesis, such as low

molecular weight, moderately high aliphatic hydroxyl number/functionality and high yields.

PF resins are most broadly used as wood adhesives in the manufacturing of

engineered wood products (e.g., plywood, particle boards and fibreboards). They are also

employed in a variety of industrial products, such as insulation, coated abrasives, paper

saturation and floral foam (Cheng et al. 2011). Bio-based PF resins from lignin can reduce

the industrial consumption of various petroleum derivative elements, such as phenol and

bisphenol A, which have high toxicity and carcinogenic effects related to both environmental

Considerable efforts have been made in phenolic resins production to replace

petroleum-based phenol either entirely or partially with lignocellulosic biomass. Browne et

al. (2011) analyzed lignin as a replacement for phenol in the synthesis of PF resins and

carbon black, and as a feed for carbon fibre production processes considering lignin

311 possibly $30 \%$ in other kinds of composite wood panels with no primary alterations in strength

312 properties. Moreover, Feng et al. (2015) concluded that bark bio-crude and neat PF adhesive 
313 were successfully blended to produce novel formulated bio PF adhesives. The authors found

314 that the ratio depends on the bark species; they reached a ratio of 50:50 (wt/wt) for white

315 birch bark, while white spruce bark bio-crude and neat PF adhesive, respectively. The

316 formulation ratio was up to 75:25 (wt/wt). Cheng et al. (2011) studied wood bio-crude to

317 replace phenol for the production of bio-based phenolic resol resins. They found that adding

318 up to $75 \mathrm{wt} \%$ (weight percent) resulted in an efficient bio-based resol resin for plywood

319 adhesives, which had comparable to better dry/wet bonding strength than the reference pure

320 PF resin. Later, Cheng et al. (2013) tested phenolic resins and adhesives from lignin/forestry

321 residuals applying a high substitution ratio of degraded lignin phenol-formaldehyde (DLPF)

322 to substitute phenol in the synthesis of bio-PF resins. Plywood samples glued with

323 organosolv lignin phenol-formaldehyde (OLPF) and DLPF adhesives (phenol replacement

324 ratio up to $75 \mathrm{wt} \%$ ) showed higher dry/wet tensile strengths than those of PF adhesives.

325 Zhang et al. (2015) demonstrated the use of kraft lignin as a promising curing agent

326 for phenol-5-hydroxymethylfurfural (PHMF) resins for thermal stability and mechanical

327 properties, for the purpose of fibreglass reinforced composite materials.

328 Within their literature review, Isikgor and Becer (2015) found that lignocellulosic

329 biomass can be utilized as a raw material to generate more than 200 value-added chemical

330 compounds, thereby proving the lignocellulosic biomass potential as a complementary

331 platform to fossil resources. For example, other than bio-based PF resins/adhesives, bio-

332 based rigid polyurethane foams were prepared by Mahmood et al. (2015) using hydrolytically

333 depolymerized kraft lignin via direct replacement or oxypropylation of depolymerized kraft

334 lignin. The resulting foam displays an excellent combination of physical, mechanical and

335 thermal properties compared to the reference foam. Table 1 summarizes papers addressing

336 lignocellulosic conversion to generate various bio-based products, chemicals and materials

337 from lignin and forest residues (e.g., epoxy resins, polyols, adhesives and PF resins among 
338 other materials and chemicals). The conversion technologies most studied for production of

339 resin and adhesives are polymerization and liquefaction (Table 1).

340 Even though there has been significant advancement in forest biomass biorefining

341 conversion technologies for value-added bio-based chemicals and materials, there are still

342 several barriers limiting their adoption within the market. Among the barriers for

343 implementation of commercial scale facilities, two key ones are logistical constraints

344 associated with maintaining a consistent supply of woody feedstock and lignin, and the high

345 capital costs of building a biorefinery (Blair 2013). Fortunately, many of these challenges can

346 be addressed through a well-designed BSC (Gold and Seuring 2011; An et al. 2011; Zhang et

347 al. 2014). A pivotally important task for developing a biorefinery is to create a reliable BSC

348 for enough feedstock at a stable price. A BSC generally starts at the cultivation level

349 (establishment and treatment of forest plantations and agricultural energy crops), going

350 through harvesting, pre-processing, transportation, handling and storage, and ultimately

351 ending at the final conversion unit, such as a biorefinery or bioenergy conversion plant (Ba et

352 al. 2015).

353 A systematic design of the entire BSC network that considers all stages, from the

354 production of forest and wood residues to the end-use of all bioproducts, is required to ensure

355 that the economic and environmental benefits be optimized (Cambero et al. 2015). Therefore,

356 an overview of BSCM and a systematic literature review of FBSC optimization based on

357 literature papers up to October 6, 2015 are presented in the following section.

358

359

4. Systematic literature review on supply chain optimization studies and their targeted

bio-based chemicals and materials

361

362

4.1 Supply chain optimization 
A BSC integrates geographically dispersed facilities where raw materials,

364 intermediate products or finished goods are acquired, transformed, stored, or marketed using transportation links that connect the facilities (Shapiro 2001; Chatfield et al. 2006).

367 supply chain optimization. The first type, known as descriptive models, includes forecasting, 368 cost relationships, resource utilization relationships and simulation models. The second type,

369 known as normative models or optimization models, are classified as linear, integer and non-

370 linear programming (Moore and Weatherford 2001). Sharma et al. (2013) concluded that the majority of recent BSC papers utilize a mixed-integer (MIP) linear programming approach, an optimization approach. The MIP models are generalizations of linear programming models in which integer variables (most commonly the binary values of 0 and 1), are constrained to take on a non-negative integer value, whereas the remaining continuous variables are allowed to take on any non-negative values (Shapiro, 2001). operational (Stadtler 2005; Shahi and Pulkki 2013). BSC Design (BSCD) and strategic planning consider a horizon of years, and involve, for example, network design, facility location(s) and process capacities. Alternatively, tactical planning and operational planning involve analyses on shorter time scales besides it commonly addresses inventory location and control, process scheduling and material flows. All scales should be analyzed collectively in an overall BSCD (Garcia and You 2015).

383 There have been an increasing number of papers addressing BSC optimization reported in some previous literature reviews. For instance, Shabani et al. (2013) analyzed 31 papers published prior to 2011. Their review focused on BSC design and analysis of

386 bioenergy production. They concluded that environmental and social objectives should be 387 included in the BSC models in addition to economic objectives. Cambero and Sowlati (2014) 
reached the same conclusion. The BSC network models were reviewed by Shahi and Pulkki

389 (2013) from the retrieved 22 papers. They found that there is a need for an integrated simulation-based optimization modeling approach in order to address uncertainties in the BSC demand and supply. In an exhaustive literature review, Elia and Floudas (2014) located 80 BSC studies regarding the production of heat, power and transportation fuels from coal, biomass and natural gas, both individually and in combination. They conclude that optimization models are most frequently applied; moreover, future studies considering multiple feedstock inputs (e.g. biomass and coal) with the focus on downstream operations and methods to address large-scale BSCs are necessary.

The most common objective of supply chain management is to minimize the total

BSC cost. This includes: raw materials and other acquisition costs; inbound transportation costs; facility investment costs; direct and indirect manufacturing and distribution costs; inventory holding costs; inter facility transportation costs; and, outbound transportation costs (Shapiro 2001). The most effective approach to supply chain management is to maximize the net revenue by maximizing the revenue while minimizing total cost (Shapiro 2001)

An optimal BSCD is vital for the forest industries' long-term success. A forest

biorefinery BSCD incorporates a wide range of biomass sources spreading out over vast geographic areas, and utilizes a variety of transport modes, ultimately generating a large number of potential BSC options. The main goal is to find the optimal logistical arrangement that minimizes annual system-wide costs, including harvesting, collection or purchasing costs, facility (storage, handling and fixed) costs, inventory holding costs and transportation costs, within the parameters of a predetermined set of requirements (Toka et al. 2010). 
413 potential changes in these circumstances (Toka et al. 2010). The number of studies

414 addressing forest BSCD has increased rapidly. Table 2 presents a summary of four papers

415 addressing BSCD. For more references, we refer to previous literature reviews: Sharma et al.

416 (2013) which reviewed 32 papers, and Cambero and Sowlati (2014) with 54 papers.

417 Selecting the optimal location for the biorefinery site is an important decision that

418 has a significant impact on the overall transportation cost (Ekşioğlu et al. 2009). The single

419 and multi-facility methods for biorefinery location(s) require the knowledge of biomass

420 feedstock locations (latitude and longitude), as well as biomass cost, availability and quality,

421 and income from by-products (Johnson et al. 2012). Transportation costs are of prime

422 importance when calculating the overall costs of biomass. Consequently, local or regional

423 production of biomass is most favourable (Demirbas 2010).

424 The location problem has been addressed in some publications extensively. For a

425 comprehensive review of BSC location models, we recommend Johnson et al. (2012). They

426 examined the methods for optimally locating a forest biomass to a bio-fuel facility, reviewing

42757 papers from 2005 to 2012 addressing this BSC problem. The authors also classified the

428 methodology used in the papers, concluding that mixed integer programming (MIP) is the

429 most applied method because it provides the most comprehensive assessment for locating

430 biorefineries overall. Nonetheless, Shahi and Pulkki (2013) found that, in general, the

431 problems solved with Linear Programming and MIP models often needed several over-

432 simplifications to render them solvable; they suggest an integrated simulation-based

433 optimization modeling approach as a better method. According to Kocoloski et al. (2011),

434 locating facilities in a way that minimizes transport cost can reduce the overall cost

435 significantly, as compared with uninformed employment.

436 The majority of the optimal location studies focus on bioenergy production, including

437 fuels, heat and power (e.g. Leduc et al. 2008; Velazquez-Marti and Fernandez-Gonzalez 
438 2010; Parker et al. 2010; Tittmann et al. 2010; Bai et al. 2011; Kim et al. 2011; Natarajan et

439 al. 2012, 2014; Palander and Voutilainen 2013; Marvin et al. 2013; Pantaleo et al. 2014).

440 However, some publications addressed BSC optimization for chemicals and materials

441 production, including location problems. For example: e.g., Zhang and Wright (2014),

442 Santibañez-Aguilar et al. (2015), Kokossis et al. (2015), Zhang et al. (2014), Sukumara et al.

443 (2014), Dansereau et al. (2014) (Table 3).

444

4.2 The targeted products in biorefineries involving forest biomass supply chain optimization

It is evident that the number of published papers on economic optimization of FBSCs

has increased significantly in the past 10 years (Figure $2 \mathrm{~b}$ ). New challenges and more

sophisticated models have been developed indicating the importance of efficient BSC design

and the evaluation of production of various products: e.g., energy, materials and chemicals

from forest biomass. Regarding the number of papers on BSC optimization, the Journal of

452 Computer and Chemical Engineering published more papers than any other journal, with

$45313.8 \%$ of the total papers, followed by Bioresource Technology, Energy, and Biomass \&

454 Bioenergy, each accounting for $8 \%$ of the total papers (Figure 2 a). The United States (U.S.)

$455(35 \%)$ and Canada (11\%) contributed to more publications than any other country (Figure 2

456 c).

457 The Canadian forest products industry needs to diversify its portfolio to remain

458 competitive, and the under-utilization of forest resources has lowered its competitiveness in

459 the global market (Shahi and Pulkki 2013). A reliable BSCD is crucial to utilize the forest

460 resources better and achieve their highest possible value. Hence, BSC optimization studies

461 are essential for the introduction of high-value bio-based products. Once such BSC

462 optimization studies are completed, analyses can be done to determine the most appropriate 
463 strategies of fibre-use to maximize value generation based on current forest market

464 conditions (Shahi and Pulkki 2013).

465 The relatively larger number of publications from Canada on BSC optimization

466 indicates that the research community has endeavoured to explore solutions and alternatives

467 for the Canadian forest industry. Additionally, the Canadian government, through Natural

468 Resources Canada (NRCan), has supported development and implementation of bioenergy

469 and biorefinery technologies (Paleologou et al. 2011). For instance, FIBRE (Forest

470 Innovation by Research and Education) was founded in 2008 with the goal of developing

471 innovative products, applications and processes, as well as policy for the forest industry

472 ("FIBRE" 2016). Under the umbrella of FIBRE, there were seven research networks funded

473 by NSERC (i.e., Value Chain Optimization Network, Bioconversion Network, Lignoworks,

474 Sentinel Bioactive Paper Network, NEWBuildS, Innovative Green Fibre Network and For

475 Value Net Network).

476 In the U.S., the Energy Independence and Security Act of 2007 (PUBLIC LAW 110-

477 140-DEC. 19, 2007) and the U.S. Environmental Protection Agency (EPA) regulate the

478 supply of renewable transportation fuels consumed through the Renewable Fuel Standard

479 (RFS2) program. According to Zhang and Wright (2014), biorefiners, renewable fuel

480 producers and other stakeholders are mandated to meet annual bio-fuel production and

481 environmental requests to obey the RFS2. The large number of papers on BSC optimization

482 from the U.S. highlights the efforts of American researchers in the production of various

483 products using renewable feedstock replacing petroleum. Regarding renewable feedstock,

484 there have been a variety of lignocellulosic sources explored within the literature, such as

485 wood chips, energy crops, forest residues, agricultural residues, corn, switch grass, mill

486 residues, and pulp and paper residues, among others. Studies focusing solely on wood as a

487 primary feedstock comprised $44.6 \%$ of the publications collected in this work, while the rest, 
$55.5 \%$ are papers involving at least one non-wood feedstock source.

Biorefineries integrate biomass conversion processes to produce various products including fuels, power, heat, and value-added chemicals and materials. Their goals are to optimize the use of bioresources and minimize wastes, thereby maximizing benefits and profitability (Kokossis et al. 2015). According to the International Energy Agency, a biorefinery should produce at least one energy product and one non-energy product (Bell et al. 2014). From the papers reviewed, it can be inferred that there is a misunderstanding of the biorefinery concept, as some papers claimed biorefinery while it was producing only bioenergy.

Figure 3 presents a classification of the targeted products in the papers reviewed in this work. The majority of the papers (approx. $85 \%$ or 56 papers) focused on bio-energy and bio-fuels production. Only about $10 \%$ of the papers targeted both bio-energy, and bio-based materials and chemicals (such as specialty chemicals, pulp and wood products, newsprint products, lignin products, furfural and commodity chemicals). Finally, less than $5 \%$ of the papers focused solely on bio-based materials and chemicals. More specifically, the main products targeted were ethanol $(\sim 40 \%)$, electricity $(\sim 23 \%)$ and heat $(\sim 23 \%)$. However, none of the papers focused on the carbon black, PF and PU resins, epoxy resins and carbon fibre, discussed in a previous section of this article.

Overall, 10 papers were targeting bio-based materials and chemicals and bioenergy (Table 3). These papers were published between 2012 and 2015, implying the emerging research interest in this field in the last couple of years.

\section{Conclusions}


513 fuels for the production of bio-based chemicals and materials as well as bioenergy and bio-

514 fuels including transportation fuels, heat and power. Forest biomass can be used as a potential

515 feedstock for biorefineries, which can ultimately help to ensure long-term environmental

516 sustainability of the industry. Supply chain optimization has been addressed and emphasized

517 in many publications. Although there are many literature review papers on biomass supply

518 chains, some questions such as "What products shall be targeted in a biorefinery based on

519 FBSC optimization?" have not yet been answered.

520 In this review paper, various lignocellulosic feedstock, potential products and conversion

521 technologies were overviewed. FBSC optimization studies were then outlined. Finally, a

522 systematic literature review was performed to discuss the target products of the BSC studies

523 for biorefineries based on forest biomass. The major findings of the literature review may be

524 summarized below:

525 (1) Novel thermochemical technologies have been developed over the years, which could

526 diversify the forest industry portfolio by enabling the production of high-value products from

527 forest biomass and mill residues. These technologies can contribute to increasing forest

528 industry competitiveness, enhance the sustainability of the forest sector and decrease

529 petroleum dependence.

530 (2) The BSC optimization has gained intensive attention in the past two years, in

531 particular in the U.S. and Canada.

532 (3) The target products in the BSC studies published so far are mainly ethanol,

533 electricity and heat, with little focus on bio-based chemicals and materials.

534 (4) A complete economic analysis and BSCD is crucial to the introduction of bio-based 535 products into the market.

$536 \quad$ (5) There is a need for further studies focusing on biorefinery and supply chain

537 optimization for the production of high-value bio-based materials and chemicals from forest 
538 biomass.

539

540 Acknowledgments

541

542 The authors acknowledge the financial support from NSERC and the Ontario

543 government through the Discovery Program, the NSERC/FPInnovations Industrial Research

544 Chair Program and the ORF-RE Program in Forest Biorefinery. One of the authors (L.D.)

545 also wants to acknowledge Science without Borders and National Council for Technological

546 and Scientific Development - Brazil for proving the scholarship for the PhD program.

547 


\section{References}

An, H., and Wilhelm, W.E. 2014. An exact solution approach based on column generation and a partial-objective constraint to design a cellulosic biofuel supply chain. Comput. Chem. Eng. 71: 11-23. doi:10.1016/j.compchemeng.2014.07.011.

An, H., Wilhelm, W.E., and Searcy, S.W. 2011. A mathematical model to design a lignocellulosic biofuel supply chain system with a case study based on a region in Central Texas. Bioresour. Technol. 102(17): 7860-7870. doi:10.1016/j.biortech.2011.05.060.

Awudu, I., and Zhang, J. 2012. Uncertainties and sustainability concepts in biofuel supply chain management: A review. Renew. Sustain. Energy Rev. 16(2): 1359-1368. doi:10.1016/j.rser.2011.10.016.

Ba, B.H., Prins, C., and Prodhon, C. 2015. Models for optimization and performance evaluation of biomass supply chains: An Operations Research perspective. Renew. Energy. doi:10.1016/j.renene.2015.07.045.

Bai, Y., Hwang, T., Kang, S., and Ouyang, Y. 2011. Biofuel refinery location and supply chain planning under traffic congestion. Transp. Res. Part B Methodol. 45(1): 162175. doi:10.1016/j.trb.2010.04.006.

Bell, G., Schuck, S., Jungmeier, G., Wellisch, M., Felby, C., Jørgensen, H., Stichnothe, H., Clancy, M., De Bari, I., Kimura, S., and others. 2014. IEA BIOENERGY Task42 BIOREFINING. IEA Bioenergy. Available from

571 Blair, J. 2013. Development of forest biorefining in Canada: overcoming the feedstock 572 barrier. Dissertation, Queen's University Kingston, Ontario. 
573 Browne, T., Gilsenan, R., Singbeil, D., and Paleologou, M. 2011. Bio-energy and Bio-

574 chemicals Synthesis Report. IPInoovations. Available from http://www.fpac.ca/publications/Bio\%20Energy\%20Final_En.pdf [accessed 7 August 2016].

Cambero, C., and Sowlati, T. 2014. Assessment and optimization of forest biomass supply

Cambero, C., Sowlati, T., Marinescu, M., and Röser, D. 2015. Strategic optimization of forest residues to bioenergy and biofuel supply chain: Forest biomass to bioenergy and biofuel supply chain. Int. J. Energy Res. 39(4): 439-452. doi:10.1002/er.3233.

Canadian Biomass. 2013. Learning About Lignin at CRIBE. Available from

Cheng, S., D'cruz, I., Wang, M., Leitch, M., and Xu, C. (Charles). 2010. Highly Efficient http://www.canadianbiomassmagazine.ca/news/learning-about-lignin-at-cribe-3970 [accessed 8 August 2016].

Chatfield, D.C., Harrison, T.P., and Hayya, J.C. 2006. SISCO: An object-oriented supply chain simulation system. Decis. Support Syst. 42(1): 422-434. doi:10.1016/j.dss.2005.02.002. Liquefaction of Woody Biomass in Hot-Compressed Alcohol-Water Co-solvents ${ }^{\dagger}$. Energy Fuels 24(9): 4659-4667. doi:10.1021/ef901218w.

Cheng, S., D’Cruz, I., Yuan, Z., Wang, M., Anderson, M., Leitch, M., and Xu, C.C. 2011. Use of biocrude derived from woody biomass to substitute phenol at a highsubstitution level for the production of biobased phenolic resol resins. J. Appl. Polym. Sci. 121(5): 2743-2751. doi:10.1002/app.33742.

Cheng, S., Wilks, C., Yuan, Z., Leitch, M., and Xu, C. (Charles). 2012a. Hydrothermal degradation of alkali lignin to bio-phenolic compounds in sub/supercritical ethanol 
and water-ethanol co-solvent. Polym. Degrad. Stab. 97(6): 839-848. doi:10.1016/j.polymdegradstab.2012.03.044.

600

Cheng, S., Yuan, Z., Anderson, M., Leitch, M., and Xu, C.C. 2012b. Synthesis of biobased

601 phenolic resins/adhesives with methylolated wood-derived bio-oil. J. Appl. Polym.

602 Sci. 126(S1): E431-E441. doi:10.1002/app.35655.

Cheng, S., Yuan, Z., Leitch, M., Anderson, M., and Xu, C. (Charles). 2013. Highly efficient de-polymerization of organosolv lignin using a catalytic hydrothermal process and production of phenolic resins/adhesives with the depolymerized lignin as a substitute for phenol at a high substitution ratio. Ind. Crops Prod. 44: 315-322. doi:10.1016/j.indcrop.2012.10.033.

Čuček, L., Martín, M., Grossmann, I.E., and Kravanja, Z. 2014. Multi-period synthesis of optimally integrated biomass and bioenergy supply network. Comput. Chem. Eng. 66: 57-70. doi:10.1016/j.compchemeng.2014.02.020.

Dansereau, L.P., El-Halwagi, M., Mansoornejad, B., and Stuart, P. 2014. Framework for margins-based planning: Forest biorefinery case study. Comput. Chem. Eng. 63: 3450. doi:10.1016/j.compchemeng.2013.12.006.

Demirbas, A. 2010. Biorefineries. Springer London, London. Available from http://link.springer.com/10.1007/978-1-84882-721-9 [accessed 13 November 2015].

\section{E. de Jong, Higson, A., Walsh, P., and Wellisch, M. 2012. Bio-based Chemicals - Value} Added Products from Biorefineries. EIA Bioenergy.

618 Ekşioğlu, S.D., Acharya, A., Leightley, L.E., and Arora, S. 2009. Analyzing the design and 619 management of biomass-to-biorefinery supply chain. Comput. Ind. Eng. 57(4): 13421352. doi:10.1016/j.cie.2009.07.003. 
621 Elia, J.A., and Floudas, C.A. 2014. Energy Supply Chain Optimization of Hybrid Feedstock

622 Processes: A Review. Annu. Rev. Chem. Biomol. Eng. 5(1): 147-179.

623 doi:10.1146/annurev-chembioeng-060713-040425.

624 Fahd, S., Fiorentino, G., Mellino, S., and Ulgiati, S. 2011. Cropping bioenergy and biomaterials in marginal land: The added value of the biorefinery concept. Energy. doi:10.1016/j.energy.2011.08.023.

Feng, S., Yuan, Z., Leitch, M., and Xu, C.C. 2014. Hydrothermal liquefaction of barks into bio-crude - Effects of species and ash content/composition. Fuel 116: 214-220. doi:10.1016/j.fuel.2013.07.096.

Feng, S., Yuan, Z., Leitch, M., and Xu, C.C. 2015. Adhesives formulated from bark biocrude and phenol formaldehyde resole. Ind. Crops Prod. 76: 258-268. doi:10.1016/j.indcrop.2015.06.056.

Ferdosian, F., Yuan, Z., Anderson, M., and Xu, C. (Charles). 2014. Synthesis of lignin-based epoxy resins: optimization of reaction parameters using response surface methodology. RSC Adv. 4(60): 31745. doi:10.1039/C4RA03978E.

FIBRE. 2016. Available from http://www.fibrenetwork.org/ [accessed 21 July 2016].

641 Garcia, D.J., and You, F. 2015. Supply chain design and optimization: Challenges and opportunities. Comput. Chem. Eng. 81: 153-170. doi:10.1016/j.compchemeng.2015.03.015. 
644 Ghatak, H.R. 2011. Biorefineries from the perspective of sustainability: Feedstocks, products, 645 and processes. Renew. Sustain. Energy Rev. 15(8): 4042-4052.

646 doi:10.1016/j.rser.2011.07.034.

647 Gold, S., and Seuring, S. 2011. Supply chain and logistics issues of bio-energy production. J. 648 Clean. Prod. 19(1): 32-42. doi:10.1016/j.jclepro.2010.08.009.

649 Green, B.N., Johnson, C.D., and Adams, A. 2001. Writing narrative literature reviews for 650 peer-reviewed journals: secrets of the trade. J. Sports Chiropr. Rehabil. 15(1): 5-19.

651 Hamel, J. 2016. Strategic directions and interest of FPInnovations. FPInnovations.

652 Holladay, J.E., Bozell, J.J., White, J.F., and Johnson, D. 2007. Top value-added chemicals 653 from biomass. DOE Rep. PNNL 16983. Available from https://www.eere.energy.gov/bioenergy/pdfs/pnnl-16983.pdf [accessed 28 February

Huang, S., Mahmood, N., Tymchyshyn, M., Yuan, Z., and Xu, C. (Charles). 2014. Reductive 2016].

Huang, S. 2014. Reductive Depolymerization of Kraft Lignin for Chemicals and Fuels Using Formic Acid as a In- Situ Hydrogen Source. Western University. Available from ir.lib.uwo.ca/cgi/viewcontent.cgi?article=3911\&context=etd [accessed 20 April 2016].

Hughes, S., R., Gibbons, W., R., Moser, B., R., and Rich, J., O. 2013. Sustainable 665 Multipurpose Biorefineries for Third-Generation Biofuels and Value-Added Co666 Products. In Biofuels - Economy, Environment and Sustainability. Edited by Z. Fang. InTech. Available from http://www.intechopen.com/books/biofuels-economy- 
environment-and-sustainability/sustainable-multipurpose-biorefineries-for-thirdgeneration-biofuels-and-value-added-co-products [accessed 10 April 2016].

671

Hurley, S., Li, H., and Xu, C. (Charles). 2010. Effects of impregnated metal ions on air/CO2gasification of woody biomass. Bioresour. Technol. 101(23): 9301-9307. doi:10.1016/j.biortech.2010.06.123.

Hurley, S., Xu, C. (Charles), Preto, F., Shao, Y., Li, H., Wang, J., and Tourigny, G. 2012.

Johnson, D.M., Jenkins, T.L., and Zhang, F. 2012. Methods for optimally locating a forest biomass-to-biofuel facility. Biofuels 3(4): 489-503. doi:10.4155/bfs. 12.34 .

690 processing network for biofuel production using an MILP model. Biomass Bioenergy 35(2): 853-871. doi:10.1016/j.biombioe.2010.11.008. 
691 Kocoloski, M., Michael Griffin, W., and Scott Matthews, H. 2011. Impacts of facility size

692 and location decisions on ethanol production cost. Energy Policy 39(1): 47-56.

693 doi:10.1016/j.enpol.2010.09.003.

694 Kokossis, A.C., Tsakalova, M., and Pyrgakis, K. 2015. Design of integrated biorefineries.

695 Comput. Chem. Eng. 81: 40-56. doi:10.1016/j.compchemeng.2015.05.021.

696 Kong, J., Rönnqvist, M., and Frisk, M. 2012. Modeling an integrated market for sawlogs,

697 pulpwood, and forest bioenergy. Can. J. For. Res. 42(2): 315-332. doi:10.1139/x11-

$698 \quad 175$.

699 Kong, J., Rönnqvist, M., and Frisk, M. 2013. Using mixed integer programming models to

700 synchronously determine production levels and market prices in an integrated market

701 for roundwood and forest biomass. Ann. Oper. Res. doi:10.1007/s10479-013-1450-0.

702 Kurian, J.K., Nair, G.R., Hussain, A., and Raghavan, G.S.V. 2013. Feedstocks, logistics and

703 pre-treatment processes for sustainable lignocellulosic biorefineries: A comprehensive

704 review. Renew. Sustain. Energy Rev. 25: 205-219. doi:10.1016/j.rser.2013.04.019.

705 Laurichesse, S., and Avérous, L. 2014. Chemical modification of lignins: Towards biobased

706 polymers. Prog. Polym. Sci. 39(7): 1266-1290.

707 doi:10.1016/j.progpolymsci.2013.11.004.

708 Leduc, S., Schwab, D., Dotzauer, E., Schmid, E., and Obersteiner, M. 2008. Optimal location

709 of wood gasification plants for methanol production with heat recovery. Int. J. Energy

$710 \quad$ Res. 32(12): 1080-1091. doi:10.1002/er.1446.

711 Li, H., Hurley, S., and Xu, C. (Charles). 2011. Liquefactions of peat in supercritical water

712 with a novel iron catalyst. Fuel 90(1): 412-420. doi:10.1016/j.fuel.2010.09.004.

713 Mafakheri, F., and Nasiri, F. 2014. Modeling of biomass-to-energy supply chain operations:

714 Applications, challenges and research directions. Energy Policy 67: 116-126.

$715 \quad$ doi:10.1016/j.enpol.2013.11.071. 
716 Mahmood, N., Yuan, Z., Schmidt, J., and (Charles) Xu, C. 2013. Production of polyols via 717 direct hydrolysis of kraft lignin: Effect of process parameters. Bioresour. Technol. 718 139: 13-20. doi:10.1016/j.biortech.2013.03.199.

719

720

721

722

723

724

725

726

727

728

729

730

731

732

733

734

735

736

737

738

739

Mahmood, N., Yuan, Z., Schmidt, J., and Xu, C. (Charles). 2015. Preparation of bio-based rigid polyurethane foam using hydrolytically depolymerized Kraft lignin via direct replacement or oxypropylation. Eur. Polym. J. 68: 1-9. doi:10.1016/j.eurpolymj.2015.04.030.

Mansoornejad, B. 2012. Design for flexibility in the forest biorefinery supply chain. École Polytechnique de Montréal. Available from http://publications.polymtl.ca/833/ [accessed 20 October 2015].

Marvin, W.A., Schmidt, L.D., and Daoutidis, P. 2013. Biorefinery Location and Technology Selection Through Supply Chain Optimization. Ind. Eng. Chem. Res. 52(9): 31923208. doi:10.1021/ie3010463.

Menon, V., and Rao, M. 2012. Trends in bioconversion of lignocellulose: Biofuels, platform chemicals \&amp; biorefinery concept. Prog. Energy Combust. Sci. 38(4): 522-550. doi:10.1016/j.pecs.2012.02.002.

Mesfun, S., and Toffolo, A. 2015. Integrating the processes of a Kraft pulp and paper mill and its supply chain. Energy Convers. Manag. 103: 300-310. doi:10.1016/j.enconman.2015.06.063.

Moore, J.H., and Weatherford, L.R. 2001. Decision Modeling with Microsoft Excel. In 6th edition. Prentice Hall, New Jersey.

Moshkelani, M., Marinova, M., Perrier, M., and Paris, J. 2013. The forest biorefinery and its implementation in the pulp and paper industry: Energy overview. Appl. Therm. Eng. 50(2): 1427-1436. doi:10.1016/j.applthermaleng.2011.12.038. 
740 Natarajan, K., Leduc, S., Pelkonen, P., Tomppo, E., and Dotzauer, E. 2012. Optimal

741 Locations for Methanol and CHP Production in Eastern Finland. BioEnergy Res. 5(2):

742 412-423. doi:10.1007/s12155-011-9152-4.

743 Natarajan, K., Leduc, S., Pelkonen, P., Tomppo, E., and Dotzauer, E. 2014. Optimal locations

744 for second generation Fischer Tropsch biodiesel production in Finland. Renew.

$745 \quad$ Energy 62: 319-330. doi:10.1016/j.renene.2013.07.013.

746 Nazari, L., Yuan, Z., Souzanchi, S., Ray, M.B., and Xu, C. (Charles). 2015. Hydrothermal

747 liquefaction of woody biomass in hot-compressed water: Catalyst screening and

$748 \quad$ comprehensive characterization of bio-crude oils. Fuel 162: 74-83.

749 doi:10.1016/j.fuel.2015.08.055.

750 Novaes, E., Kirst, M., Chiang, V., Winter-Sederoff, H., and Sederoff, R. 2010. Lignin and

751 Biomass: A Negative Correlation for Wood Formation and Lignin Content in Trees.

752 PLANT Physiol. 154(2): 555-561. doi:10.1104/pp.110.161281.

753 Palander, T.S., and Voutilainen, J.J. 2013. Modelling fuel terminals for supplying a combined

754 heat and power (CHP) plant with forest biomass in Finland. Biosyst. Eng. 114(2):

755 135-145. doi:10.1016/j.biosystemseng.2012.11.005.

756 Paleologou, M., Radiotis, T., Kouisni, L., Jemaa, N., Mahmood, T., Browne, T., and

757 Singbeil, D. 2011. New and emerging biorefinery technologies and products for the

758 Canadian forest industry. J--J. Sci. Technol. For. Prod. Process. 1(3): 6.

759 Pandey, M.P., and Kim, C.S. 2011. Lignin Depolymerization and Conversion: A Review of

760 Thermochemical Methods. Chem. Eng. Technol. 34(1): 29-41.

$761 \quad$ doi:10.1002/ceat.201000270.

762 Pantaleo, A.M., Giarola, S., Bauen, A., and Shah, N. 2014. Integration of biomass into urban

763 energy systems for heat and power. Part I: An MILP based spatial optimization 
methodology. Energy Convers. Manag. 83: 347-361.

766 doi:10.1016/j.enconman.2014.03.050.

Parker, N., Tittmann, P., Hart, Q., Nelson, R., Skog, K., Schmidt, A., Gray, E., and Jenkins, B. 2010. Development of a biorefinery optimized biofuel supply curve for the

PUBLIC LAW 110-140-DEC. 19, 2007. 2007. ENERGY INDEPENDENCE AND Western United States. Biomass Bioenergy 34(11): 1597-1607. doi:10.1016/j.biombioe.2010.06.007.

Petticrew, M., and Roberts, H. 2006. Systematic reviews in the social sciences: a practical guide. Blackwell Pub, Malden, MA; Oxford.

\section{SECURITY ACT OF 2007.}

Reyhanitash, E., Tymchyshyn, M., Yuan, Z., Albion, K., van Rossum, G., and Xu, C. (Charles). 2014. Upgrading Fast Pyrolysis Oil via Hydrodeoxygenation and Thermal Treatment: Effects of Catalytic Glycerol Pretreatment. Energy Fuels 28(2): 11321138. doi:10.1021/ef402227m.

Santibañez-Aguilar, J.E., Rivera-Toledo, M., Flores-Tlacuahuac, A., and Ponce-Ortega, J.M. 2015. A mixed-integer dynamic optimization approach for the optimal planning of distributed biorefineries. Comput. Chem. Eng. 80: 37-62. doi:10.1016/j.compchemeng.2015.05.008.

Scott, J.A., Ho, W., and Dey, P.K. 2012. A review of multi-criteria decision-making methods for bioenergy systems. Energy 42(1): 146-156. doi:10.1016/j.energy.2012.03.074.

Shabani, N., Akhtari, S., and Sowlati, T. 2013. Value chain optimization of forest biomass for bioenergy production: A review. Renew. Sustain. Energy Rev. 23: 299-311. doi:10.1016/j.rser.2013.03.005. 
787 Shahi, S., and Pulkki, R. 2013. Supply Chain Network Optimization of the Canadian Forest

788 Products Industry: A Critical Review. Am. J. Ind. Bus. Manag. 03(07): 631-643.

789 doi:10.4236/ajibm.2013.37073.

790 Shapiro, J.F. 2001. Modeling the Supply Chain. In 2nd edition. Pacific Grove: Thompson

791 Learning, Massachusetts Institute of Technology.

792 Sharma, B., Ingalls, R.G., Jones, C.L., and Khanchi, A. 2013. Biomass supply chain design

793 and analysis: Basis, overview, modeling, challenges, and future. Renew. Sustain.

794 Energy Rev. 24: 608-627. doi:10.1016/j.rser.2013.03.049.

795 Shen, D., Jin, W., Hu, J., Xiao, R., and Luo, K. 2015. An overview on fast pyrolysis of the

796 main constituents in lignocellulosic biomass to valued-added chemicals: Structures,

797 pathways and interactions. Renew. Sustain. Energy Rev. 51: 761-774.

798 doi:10.1016/j.rser.2015.06.054.

799 Sjöström, E. 1993. Wood chemistry: fundamentals and applications. In 2nd edition.

$800 \quad$ Academic Press, Inc, San Diego.

801 Srirangan, K., Akawi, L., Moo-Young, M., and Chou, C.P. 2012. Towards sustainable

802 production of clean energy carriers from biomass resources. Appl. Energy 100: 172-

803 186. doi:10.1016/j.apenergy.2012.05.012.

804 Stadtler, H. 2005. Supply chain management and advanced planning — basics, overview and

805 challenges. Eur. J. Oper. Res. 163(3): 575-588. doi:10.1016/j.ejor.2004.03.001.

806 Sukumara, S., Faulkner, W., Amundson, J., Badurdeen, F., and Seay, J. 2014. A

807 multidisciplinary decision support tool for evaluating multiple biorefinery conversion

808 technologies and supply chain performance. Clean Technol. Environ. Policy 16(6):

809 1027-1044. doi:10.1007/s10098-013-0703-6. 
810 Thiffault, E., Lorente, M., Murray, J., and Fritsche, U. 2014. Ecological sustainability of

811 wood bioenergy feedstock supply chains: Local, national and international policy 812 perspectives. EIA.

813 Tittmann, P.W., Parker, N.C., Hart, Q.J., and Jenkins, B.M. 2010. A spatially explicit techno814 economic model of bioenergy and biofuels production in California. J. Transp. Geogr. 815 18(6): 715-728. doi:10.1016/j.jtrangeo.2010.06.005.

816 Toka, A., Iakovou, E., and Vlachos, D. 2010. Biomass supply chain management for energy

817 polygeneration systems. In Proceedings of the 1st Olympus International Conference 818 on Supply Chains. Greece. pp. 1-2. Available from 819 http://www.teicm.gr/logistics/images/logisticsdocs/icsc2010/fullabstracts/1_1_ICSC2 820 010_066_Toka_et_al.pdf [accessed 20 November 2015].

821 Tong, K., Gleeson, M.J., Rong, G., and You, F. 2014. Optimal design of advanced drop-in 822 hydrocarbon biofuel supply chain integrating with existing petroleum refineries under 823 uncertainty. Biomass Bioenergy 60: 108-120. doi:10.1016/j.biombioe.2013.10.023.

824 Tymchyshyn, M., and Xu, C. (Charles). 2010. Liquefaction of bio-mass in hot-compressed 825 water for the production of phenolic compounds. Bioresour. Technol. 101(7): 2483826 2490. doi:10.1016/j.biortech.2009.11.091.

827 Velazquez-Marti, B., and Fernandez-Gonzalez, E. 2010. Mathematical algorithms to locate 828 factories to transform biomass in bioenergy focused on logistic network construction.

829 Renew. Energy 35(9): 2136-2142. doi:10.1016/j.renene.2010.02.011.

830 Wang, M., Leitch, M., and (Charles) Xu, C. 2009. Synthesis of phenol-formaldehyde resol 831 resins using organosolv pine lignins. Eur. Polym. J. 45(12): 3380-3388.

832 doi:10.1016/j.eurpolymj.2009.10.003. 
833 Wang, M., Yuan, Z., Cheng, S., Leitch, M., and Xu, C.C. 2010. Synthesis of novolac-type

834 phenolic resins using glucose as the substitute for formaldehyde. J. Appl. Polym. Sci.:

835 n/a-n/a. doi:10.1002/app.32240.

836 Werpy, T. 2009. BIO-World conference in Biotechnology and Bioprocessing. Montreal.

837 Williams, C.L., Westover, T.L., Emerson, R.M., Tumuluru, J.S., and Li, C. 2016. Sources of

838 Biomass Feedstock Variability and the Potential Impact on Biofuels Production.

839 BioEnergy Res. 9(1): 1-14. doi:10.1007/s12155-015-9694-y.

840 Yang, Y., Gilbert, A., and Xu, C. (Charles). 2009a. Production of bio-crude from forestry

841 waste by hydro-liquefaction in sub-/super-critical methanol. AIChE J. 55(3): 807-

842 819. doi:10.1002/aic.11701.

843 Yang, Y., Gilbert, A., and Xu, C. (Charles). 2009b. Hydrodeoxygenation of bio-crude in

844 supercritical hexane with sulfided CoMo and CoMoP catalysts supported on MgO: A

845 model compound study using phenol. Appl. Catal. Gen. 360(2): 242-249.

846 doi:10.1016/j.apcata.2009.03.027.

847 Yuan, Z., Cheng, S., Leitch, M., and Xu, C. (Charles). 2010. Hydrolytic degradation of

848 alkaline lignin in hot-compressed water and ethanol. Bioresour. Technol. 101(23):

849 9308-9313. doi:10.1016/j.biortech.2010.06.140.

850 Yuan, Z., Xu, C. (Charles), Cheng, S., and Leitch, M. 2011. Catalytic conversion of glucose

851 to 5-hydroxymethyl furfural using inexpensive co-catalysts and solvents. Carbohydr.

852 Res. 346(13): 2019-2023. doi:10.1016/j.carres.2011.06.007.

853 Yuan, Z., Zhang, Y., and Xu, C. (Charles). 2014. Synthesis and thermomechanical property

854 study of Novolac phenol-hydroxymethyl furfural (PHMF) resin. RSC Adv. 4(60):

855

31829. doi:10.1039/C4RA04458D. 
856 Yue, D., You, F., and Snyder, S.W. 2014. Biomass-to-bioenergy and biofuel supply chain

857 optimization: Overview, key issues and challenges. Comput. Chem. Eng. 66: 36-56.

858 doi:10.1016/j.compchemeng.2013.11.016.

859

Zhang, L., Champagne, P., and (Charles) Xu, C. 2011a. Bio-crude production from secondary

860 pulp/paper-mill sludge and waste newspaper via co-liquefaction in hot-compressed

861 water. Energy 36(4): 2142-2150. doi:10.1016/j.energy.2010.05.029.

862

Zhang, L., Champagne, P., and (Charles) Xu, C. 2011b. Supercritical water gasification of an

863

864 aqueous by-product from biomass hydrothermal liquefaction with novel Ru modified

865 Ni catalysts. Bioresour. Technol. 102(17): 8279-8287.

866 doi:10.1016/j.biortech.2011.06.051.

Zhang, L., Champagne, P., and Xu, C. (Charles). 2011c. Screening of supported transition

Zhang, L., Xu, C. (Charles), and Champagne, P. 2010a. Energy recovery from secondary pulp/paper-mill sludge and sewage sludge with supercritical water treatment $\_$.

Zhang, L., Xu, C. (Charles), and Champagne, P. 2010b. Overview of recent advances in thermo-chemical conversion of biomass. Energy Convers. Manag. 51(5): 969-982. doi:10.1016/j.enconman.2009.11.038. modified Ni catalyst for hydrogen generation by supercritical water gasification of glucose. Fuel 96: 541-545. doi:10.1016/j.fuel.2012.01.066. 
879 Zhang, Y., Hu, G., and Brown, R.C. 2014. Integrated supply chain design for commodity

880 chemicals production via woody biomass fast pyrolysis and upgrading. Bioresour.

$881 \quad$ Technol. 157: 28-36. doi:10.1016/j.biortech.2014.01.049.

882 Zhang, Y., and Wright, M.M. 2014. Product Selection and Supply Chain Optimization for

883 Fast Pyrolysis and Biorefinery System. Ind. Eng. Chem. Res. 53(51): 19987-19999.

884 doi:10.1021/ie503487d.

885 Zhang, Y., Yuan, Z., and Xu, C.C. 2015. Engineering biomass into formaldehyde-free

886 phenolic resin for composite materials. AIChE J. 61(4): 1275-1283.

887 doi:10.1002/aic.14716.

888

889 
891

892

893

894

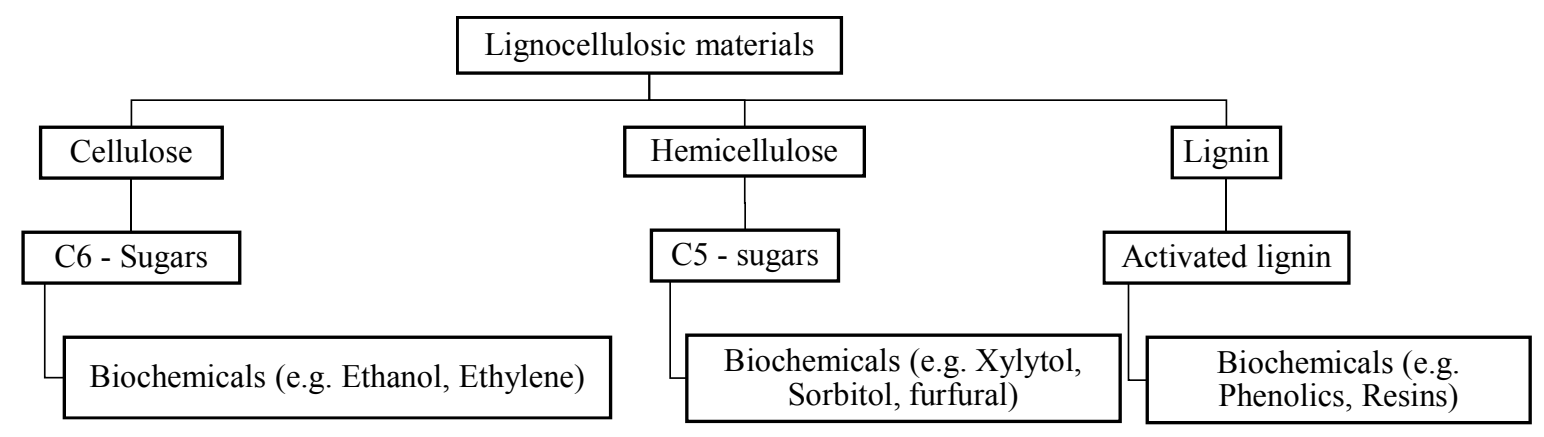

895 Figure 1. Potential value-added biochemicals of a lignocellulosic biorefinery. 
a) \% of apers by Journal

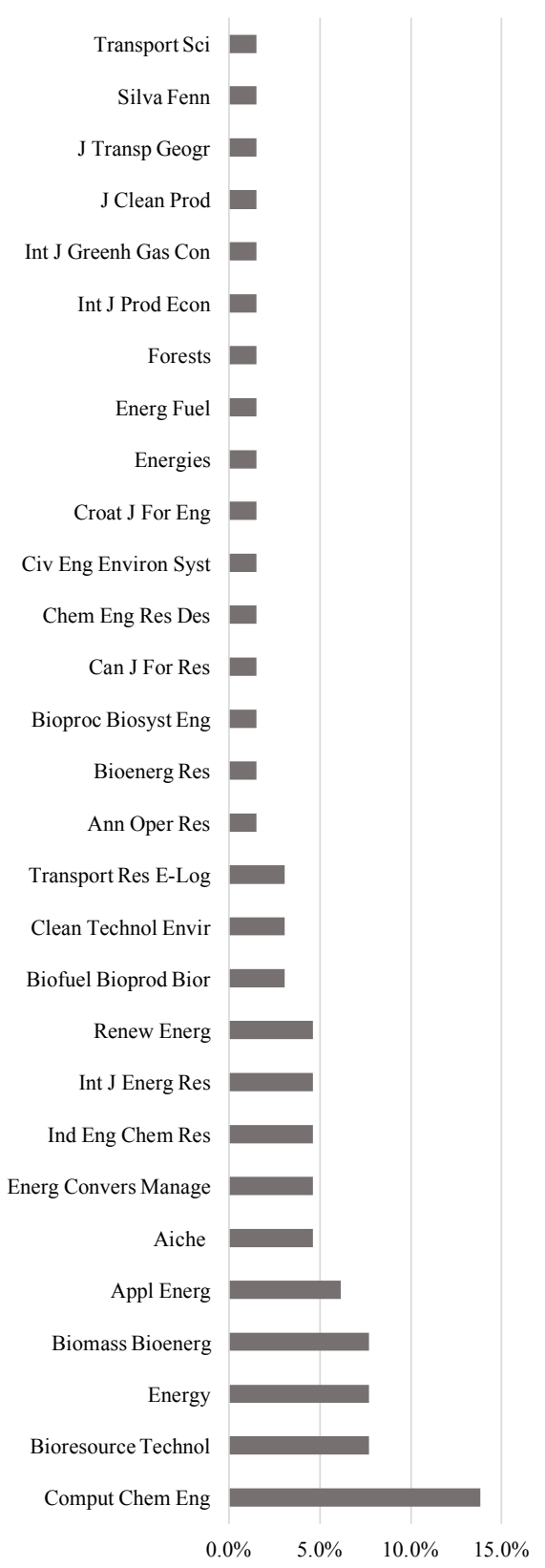

b) $\%$ of papers by year

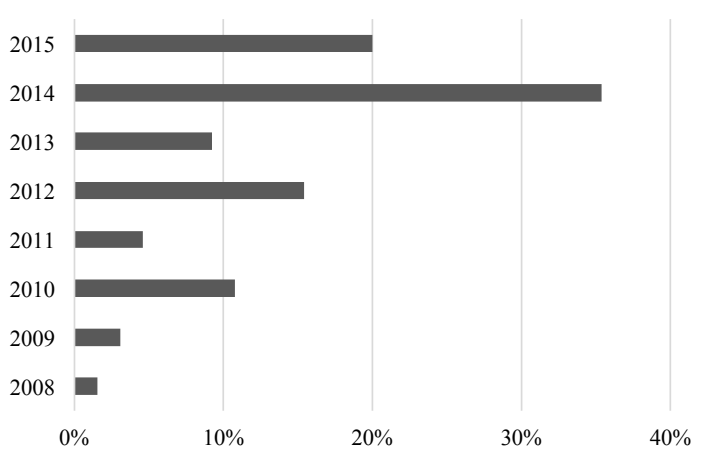

c) \% papers by country

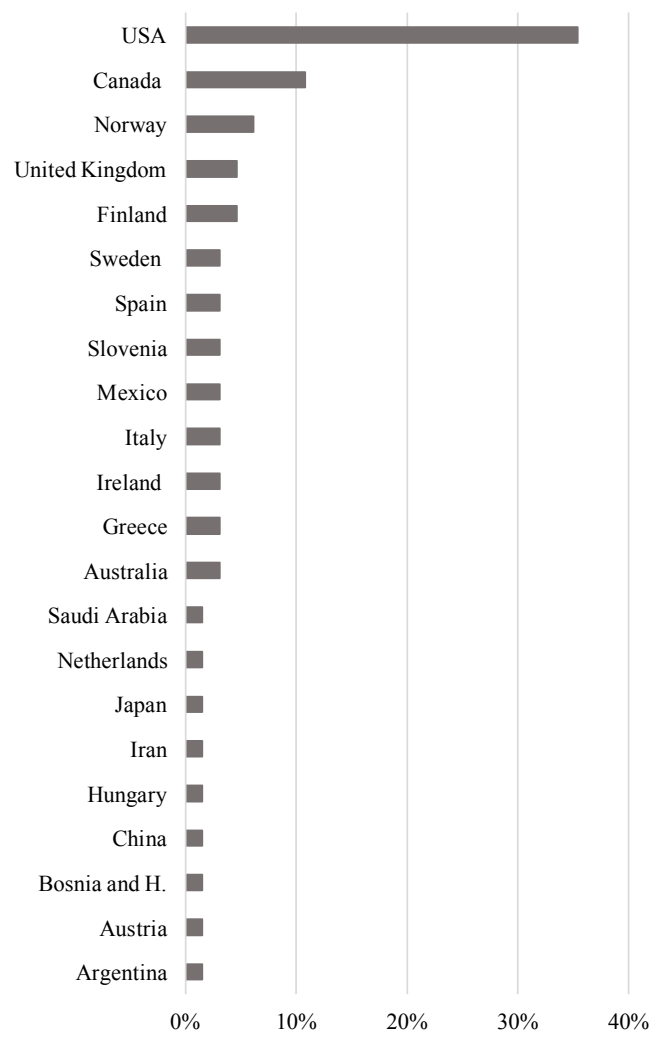

898 Figure 2. Papers reviewed percentage by journal (a), by year (b), and by country (c). The 899 review includes publications up to October 6, 2015. 


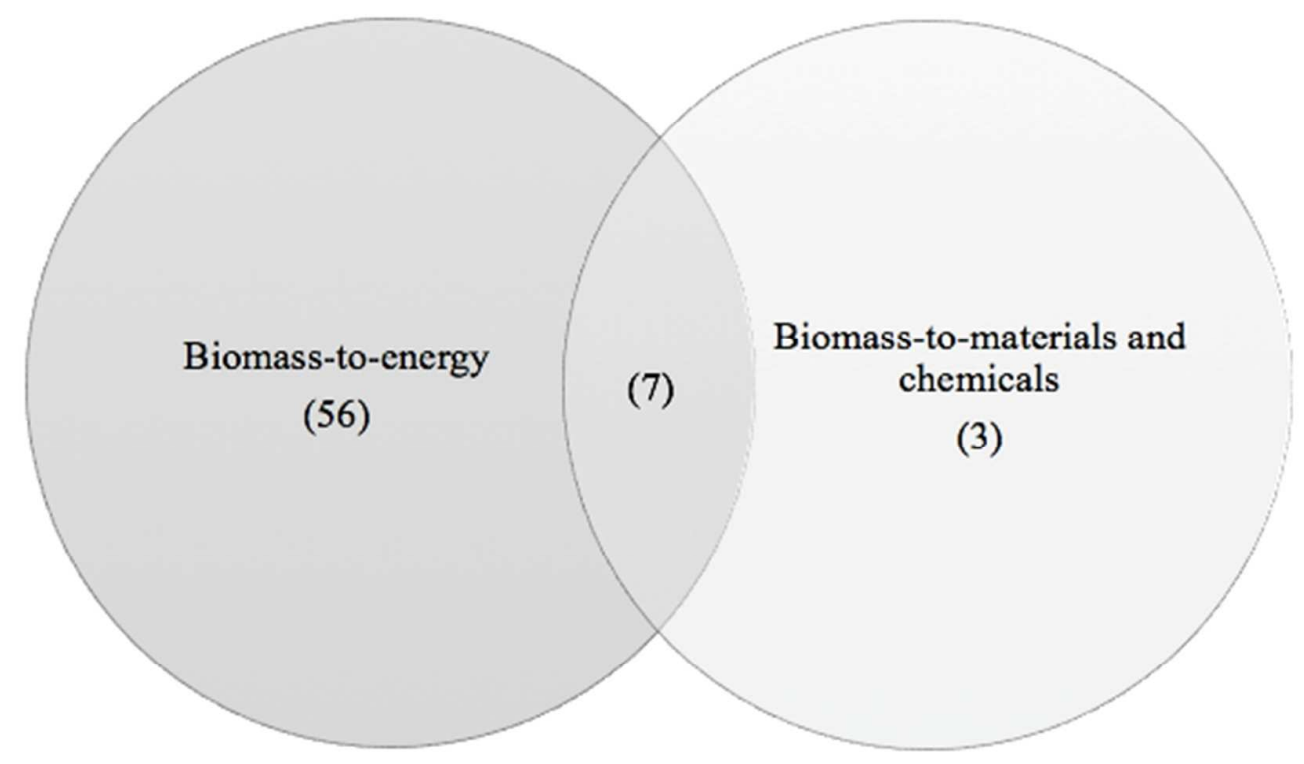

904 Figure 3. Final product of the FBSC economic optimization from the 66 reviewed papers. 
1 Table 1. Summary of papers regarding thermochemical technologies for new bio-based products from lignin and forest residues.

\begin{tabular}{|c|c|c|c|}
\hline Conversion technologies & Raw material & Final product & Reference \\
\hline Co-catalysts and solvents & Glucose & 5-hydroxymethyl furfural & Yuan et al. (2011) \\
\hline Co-liquefaction in hot-compressed water & Secondary pulp/paper-mill sludge & Bio-crude & Zhang et al. (2011a) \\
\hline Deligninfication & $\begin{array}{l}\text { Bio-phenolic compounds from } \\
\text { lignin/forestry residuals (pine sawdust) }\end{array}$ & Phenolic resins and adhesives & Cheng et al. (2013) \\
\hline \multirow[b]{2}{*}{ Depolymerization } & Hydrolysis lignin & Polyurethane foams/resins & Mahmood et al. (2015) \\
\hline & Kraft lignin & $\begin{array}{l}\text { De-polymerized lignin } \\
\text { Lignin-based epoxy resins }\end{array}$ & $\begin{array}{l}\text { Huang et al. (2014) } \\
\text { Ferdosian et al. (2015) }\end{array}$ \\
\hline Depolymerization in supercritical acetone & Kraft lignin & Epoxy resin & Ferdosian et al. (2014) \\
\hline Direct hydrolysis & Kraft lignin & Polyols & Mahmood et al. (2013) \\
\hline \multirow[t]{2}{*}{ Direct liquefaction } & Eastern white pine sawdust & $\begin{array}{l}\text { Bio-oil } \\
\text { Bio-based Phenolic Resol } \\
\text { Resins }\end{array}$ & $\begin{array}{l}\text { Cheng et al. (2010; } \\
\text { 2011) }\end{array}$ \\
\hline & $\begin{array}{l}\text { Sawdust, cornstalks, pure lignin and } \\
\text { pure cellulose as references }\end{array}$ & Phenol-formaldehyde resins & $\begin{array}{l}\text { Tymchyshyn and } \mathrm{Xu} \\
\text { (2010) }\end{array}$ \\
\hline Fast Pyrolysis & Hardwood sawdust & Pyrolysis oil & $\begin{array}{l}\text { Reyhanitash et al. } \\
\text { (2014) }\end{array}$ \\
\hline Gasification & Pine sawdust & Combustible gas & $\begin{array}{l}\text { Hurley et al. (2010; } \\
\text { 2012) }\end{array}$ \\
\hline Glucose as the replacement of formaldehyde & Glucose & Novolac-Type Phenolic Resins & Wang et al. (2010) \\
\hline $\begin{array}{l}\text { Hydro-Liquefaction in Sub-Super-Critical } \\
\text { Methanol }\end{array}$ & Woody biomass (birch powder) & Bio-crude & Yang et al. (2009a) \\
\hline Hydrodeoxygenation & Bio-crude & Oily products & Yang et al. (2009b) \\
\hline $\begin{array}{l}\text { Hydrolytic degradation in hot-compressed } \\
\text { water }\end{array}$ & \multirow{2}{*}{ Alkali lignin } & Oligomers & Yuan et al. (2010) \\
\hline Hydrothermal degradation & & Bio-phenolic compounds & Cheng et al. (2012a) \\
\hline
\end{tabular}


6 Table 1: Continued.

\begin{tabular}{|c|c|c|c|}
\hline Conversion technologies & Raw material & Final product & Reference \\
\hline \multirow[b]{2}{*}{ Hydrothermal liquefaction } & Birchwood sawdust & Bio-crude & Nazari et al. (2015) \\
\hline & Eastern white pine sawdust & $\begin{array}{l}\text { Methylolated bio-oil-PF resol } \\
\text { resins }\end{array}$ & Cheng et al. (2012b) \\
\hline \multirow[t]{2}{*}{ Liquefaction } & $\begin{array}{l}\text { Bark (white pine, white spruce and white } \\
\text { birch) }\end{array}$ & Bio-crude & Feng et al. (2014) \\
\hline & White birch bark and white spruce bark & BPF adhesives & Feng et al. (2015) \\
\hline One pot synthesis process & \multirow{2}{*}{ Kraft lignin } & $\begin{array}{l}\text { Formaldehyde-free phenolic } \\
\text { resin }\end{array}$ & Zhang et al. (2015) \\
\hline Organosolv extraction & & $\begin{array}{l}\text { Phenol-formaldehyde resol } \\
\text { resins }\end{array}$ & Wang et al. (2009) \\
\hline $\begin{array}{l}\text { Phenol-5-hydroxymethyl furfural resins } \\
\text { synthesized by reacting phenol with 5- } \\
\text { hydroxymethyl furfural }\end{array}$ & Glucose & $\begin{array}{l}\text { Fibre-glass reinforced plastic } \\
\text { (FRP) }\end{array}$ & Yuan et al. (2014) \\
\hline \multirow{3}{*}{ Supercritical water gasification } & Glucose & $\mathrm{H}_{2}$ & $\begin{array}{l}\text { Zhang et al. (2012) } \\
\text { Zhang et al. (2011c) }\end{array}$ \\
\hline & $\begin{array}{l}\text { Pulp/paper mill sludge, sewage sludges } \\
\text { (primary, secondary, and digested) }\end{array}$ & Bioenergy & Zhang et al. (2010b) \\
\hline & Sludge (secondary pulp/paper-mill) & $\mathrm{H}_{2}$ & Zhang et al. (2011b) \\
\hline
\end{tabular}


Table 2. Summary of recent BSCD papers for bioenergy and biochemicals production.

\begin{tabular}{|c|c|c|c|}
\hline Reference & Mathematical model & Model objective & Main findings \\
\hline $\begin{array}{l}\text { Zhang et al. } \\
\text { (2014) }\end{array}$ & $\begin{array}{l}\text { Mixed Integer Linear } \\
\text { Programming (MILP) }\end{array}$ & $\begin{array}{l}\text { Maximizing profit for commodity } \\
\text { chemicals production via woody } \\
\text { biomass fast pyrolysis and hydro } \\
\text { processing pathways. }\end{array}$ & $\begin{array}{l}\text { For a case study of Minnesota, U.S., the model demonstrated that } \\
\text { distributed biomass chipping facilities are more profitable than } \\
\text { roadside chipping, rich biomass sites are preferable locations for } \\
\text { building a biorefinery, also that biomass availability and facility } \\
\text { capital costs are the most significant variables affecting the project } \\
\text { profitability. }\end{array}$ \\
\hline $\begin{array}{l}\text { Cambero et al. } \\
\text { (2015) }\end{array}$ & $\begin{array}{l}\text { Multi-period MILP } \\
\text { model }\end{array}$ & $\begin{array}{l}\text { Optimize the BSCD of forest } \\
\text { residues for the production of } \\
\text { bioenergy. }\end{array}$ & $\begin{array}{l}\text { The model recommended the installation of small biomass boilers } \\
\text { coupled with steam turbines for electricity production and pyrolysis } \\
\text { plants to supply the needs of Williams Lake timber supply area, in } \\
\text { British Columbia, Canada. }\end{array}$ \\
\hline $\begin{array}{l}\text { Čuček et al. } \\
(2014)\end{array}$ & MILP & $\begin{array}{l}\text { Optimally integrate regional biomass } \\
\text { and bioenergy supply network } \\
\text { including production processes from } \\
\text { different sources of biomass } \\
\text { producing first, second and third } \\
\text { generation biofuels. }\end{array}$ & $\begin{array}{l}\text { It is feasible to produce second and third generation biofuels. } \\
\text { Biomass and waste, especially switchgrass and algae, were found to } \\
\text { be promising raw materials for producing biofuels. Biorefinery } \\
\text { supply networks could reveal significant unburdening capabilities } \\
\text { of GHG emissions. }\end{array}$ \\
\hline $\begin{array}{l}\text { Tong et al. } \\
\text { (2014) }\end{array}$ & $\begin{array}{l}\text { Multi-period MILP } \\
\text { model }\end{array}$ & $\begin{array}{l}\text { Optimizing the BSCD for an } \\
\text { advanced drop-in hydrocarbon bio- } \\
\text { fuel BSC, integrating with existing. } \\
\text { petroleum refineries under } \\
\text { uncertainty. }\end{array}$ & $\begin{array}{l}\text { Their model demonstrates, through a case study of Illinois, that } \\
\text { advanced hydrocarbon biofuel BSC integrated with existing } \\
\text { petroleum refinery infrastructure significantly reduces capital cost } \\
\text { and total annualized cost, when compared to traditional biofuel } \\
\text { BSCs. }\end{array}$ \\
\hline
\end{tabular}


Table 3. Summary of the 10 papers addressing bioenergy, biochemicals and biomaterials.

\begin{tabular}{|c|c|c|c|c|}
\hline Reference & Research objectives & Feedstock & Target Products & Main findings \\
\hline $\begin{array}{l}\text { Zhang et al. } \\
(2014)\end{array}$ & See Table 2 & Forest residues. & $\begin{array}{l}\text { Commodity } \\
\text { chemicals }\end{array}$ & See Table 2 \\
\hline $\begin{array}{l}\text { Kokossis et al. } \\
(2015)\end{array}$ & $\begin{array}{l}\text { Developing a systems approach for the } \\
\text { design of integrated biorefineries, } \\
\text { finding the most profitable biorefinery } \\
\text { portfolio. }\end{array}$ & $\begin{array}{l}\text { Wheat straw, rice; } \\
\text { poplar and birch. }\end{array}$ & $\begin{array}{l}37 \text { chemical } \\
\text { compounds, } 20 \\
\text { intermediates, and } 17 \\
\text { final products. }\end{array}$ & $\begin{array}{l}\text { Total site integration was found } \\
\text { to offer savings of up to } 88 \% \\
\text { when compared with the non- } \\
\text { integrated case. The final } \\
\text { products selected were xylonic } \\
\text { acid, polyamide } 2 \text {, polyester, } \\
\text { polyamide }{ }_{3} \text {, lignin-based castor } \\
\text { oil, polyurethane coating, and } \\
\text { resins. }\end{array}$ \\
\hline $\begin{array}{l}\text { Mesfun and } \\
\text { Toffolo (2015) }\end{array}$ & $\begin{array}{l}\text { Integration of a pulp and paper mill and } \\
\text { a wood-pellet plant that share a heat and } \\
\text { power plant. }\end{array}$ & $\begin{array}{l}\text { Pulp wood, roundwood } \\
\text { sawdust and wood } \\
\text { chips. }\end{array}$ & $\begin{array}{l}\text { Heat, power, pulp, } \\
\text { lumber and wood } \\
\text { pellets. }\end{array}$ & $\begin{array}{l}\text { The integrated cases studied } \\
\text { performed better economically } \\
\text { than the standalone ones in terms } \\
\text { of investment opportunity. }\end{array}$ \\
\hline $\begin{array}{l}\text { Kong et al. } \\
(2012)\end{array}$ & $\begin{array}{l}\text { To develop an optimization model to } \\
\text { integrate the roundwood and forest } \\
\text { biomass value chains in the initial stage } \\
\text { of the FBSCs. Minimizing costs of } \\
\text { procurement, chipping, inventory, and } \\
\text { transportation. }\end{array}$ & $\begin{array}{l}\text { Sawlogs, pulpwood, and } \\
\text { forest residues, and } \\
\text { wood chips and bark. }\end{array}$ & $\begin{array}{l}\text { Heat, pulp and wood } \\
\text { products. }\end{array}$ & $\begin{array}{l}\text { In an integrated market there may } \\
\text { be competition between heat } \\
\text { generation and pulp because } \\
\text { pulpwood can be used as raw } \\
\text { material in both. }\end{array}$ \\
\hline
\end{tabular}


Table 3: Continued.

\begin{tabular}{|c|c|c|c|c|}
\hline Reference & Research objectives & Feedstock & Target Products & Main findings \\
\hline $\begin{array}{l}\text { Kong et al. } \\
(2013)\end{array}$ & $\begin{array}{l}\text { Improvements the model published in } \\
2012 \text { in order to address log-term } \\
\text { planning. They presented a new } \\
\text { approach that can jointly choose areas } \\
\text { and define price levels for different } \\
\text { assortments at the chosen supply points } \\
\text { of the BSC in the long term planning. }\end{array}$ & $\begin{array}{l}\text { Sawlogs, pulpwood, } \\
\text { forest residues, wood } \\
\text { chips and bark. }\end{array}$ & $\begin{array}{l}\text { Heat, pulp and wood } \\
\text { products. }\end{array}$ & $\begin{array}{l}\text { With their model different } \\
\text { equilibrium prices for roundwood } \\
\text { and forest biomass can be } \\
\text { generated, and possible } \\
\text { unprofitable supply points can be } \\
\text { excluded. }\end{array}$ \\
\hline $\begin{array}{l}\text { Dansereau et al. } \\
(2014)\end{array}$ & $\begin{array}{l}\text { Integrating BSC planning and } \\
\text { framework to optimize a superstructure } \\
\text { that would ultimately assist decision } \\
\text { makers to create BSC policies that can } \\
\text { readily adjust to market changes. }\end{array}$ & $\begin{array}{l}\text { Recycles paper, logs, } \\
\text { and chips. }\end{array}$ & $\begin{array}{l}\text { Newsprint products, } \\
\text { lignin products, } \\
\text { furfural, ethanol and } \\
\text { heat. }\end{array}$ & $\begin{array}{l}\text { By applying key concepts of the } \\
\text { margins-based framework a } \\
\text { company could increase its } \\
\text { performance and robustness } \\
\text { through BSC planning. }\end{array}$ \\
\hline $\begin{array}{l}\text { Zhang and } \\
\text { Wright (2014) }\end{array}$ & $\begin{array}{l}\text { Determinate the optimal plant sizes, } \\
\text { locations, and product distributions for } \\
\text { an integrated fast pyrolysis biorefinery } \\
\text { BSC. }\end{array}$ & Forest residues. & $\begin{array}{l}\text { Hydrogen, liquid } \\
\text { fuels, commodity } \\
\text { chemicals, and } \\
\text { lignin. }\end{array}$ & $\begin{array}{l}\text { Liquid fuel prices influence the } \\
\text { annualized profit more then the } \\
\text { commodity chemical price. }\end{array}$ \\
\hline $\begin{array}{l}\text { Čuček et al. } \\
(2014)\end{array}$ & See Table 2 & $\begin{array}{l}\text { Corn grains, wood chips } \\
\text { municipal solid waste, } \\
\text { corn stover, organic } \\
\text { manure and timber. }\end{array}$ & $\begin{array}{l}\text { Heat, electricity, } \\
\text { Ethanol, Corn-food, } \\
\text { digestate boards, and } \\
\text { distillers dried grains } \\
\text { with solubles. }\end{array}$ & See Table 2 \\
\hline
\end{tabular}

